\title{
WCIELENIE SŁOWA BOŻEGO W TEOLOGII APOLINAREGO Z LAODYCEI NA TLE KONTROWERSJI ARIAŃSKIEJ
}

Chrystologia Apolinarego z Laodycei jest żelaznym punktem każdej historii dogmatu i podręcznika patrologii. Jego poglądy są bowiem dostatecznie ważne, by się nimi zajmować, nawet jeśli ich wpływ można traktować jako negatywny, to znaczy zmuszający innych do precyzyjniejszego wyrażania się, bez pójścia za nimi. Pamiętamy też, że jego slogan, ,jedna natura wcielonego Słowa" stał się hasłem monofizytów, mimo prób jego obrony przez Cyryla Aleksandryjskiego. Tak więc poświęca im uwagę Kelly ${ }^{1}$, Sesboüé z Wolińskim $^{2}$, Kulisz w swym podręczniku chrystologii ${ }^{3}$, czy ja sam ${ }^{4}$. Dla większości $\mathrm{z}$ nas, autorów tych publikacji, punktem odniesienia jest monumentalne dzieło Grillmeiera $^{5}$, i na ogół nie odchodzi się raczej daleko od jego interpretacji. Nie miałoby więc większego sensu, by powtarzać tutaj utarte już sformułowania czy osądy. Bliższa analiza tych opracowań wskazuje jednak na pewien ambaras związany ze znanym powszechnie antyarianizmem Apolinarego. W tej prezentacji postaram się zatem przedstawić pokrótce poglądy Apolinarego na podstawie tylko jego pism, a raczej tej marnej reszty, jaka dotarła do naszych czasów, a następnie i przede wszystkim poszukam odpowiedzi na pytanie, dlaczego są one antyariańskie. Innymi słowy mówiąc: jak pojmował Apolinary arianizm, że w odpowiedzi nań skonstruował taką, a nie inną teorię. Oczywiście ciągle chodzić będzie tylko o wcielenie Słowa Bożego.

W Szczegótowym wykładzie wiary rozpoczyna Apolinary od wyszczególnienia tych poglądów, z którymi się nie zgadza i które ma zamiar zwalczać. Możemy je wyliczyć:

${ }^{1}$ J. N. D. Kelly, Początki doktryny chrześcijańskiej, tłum. J. Mrukówna, Warszawa 1988, 217-221.

2 B. Sesboüé - J. Woliński, Bóg zbawienia, tłum. P. Rak, Kraków 1999, 314- 317.

3 J. Kulisz, Spór o Jezusa Chrystusa w ciqgu dziejów, Warszawa 1998, 133-141.

${ }^{4}$ H. Pietras, Początki teologii Kościoła, Kraków 2000, 213-215.

${ }^{5}$ A. Grillmeier, Gesù il Cristo nella fede della Chiesa, I, 1, Brescia 1982, 607-626, lub inne wersje językowe. 
1. Syn jest z niczego i został jedynie ustanowiony Synem otrzymując Królestwo;

2. Również Duch Święty jest z niczego;

3. Syn jest ubóstwiony przez łaskę, a Duch uświęcony;

4. Syn jest tylko pierwszym ze stworzeń;

5. Syn jest zrodzony w pewnym momencie;

6. Każdej z Osób Boskich przysługuje odrębny kult;

7. Nie ma w Trójcy trzech Osób, ale Monada ${ }^{6}$.

Twierdzenia 1, 2, 4 i 5 wyglądają na ariańskie, 3 - na ariańskie a równocześnie Pawłowe, w sensie Pawła z Samosaty, 6 - jest tryteistyczne, a 7 monarchiańskie. Wyraźnie więc Apolinary umieszcza się w środku między różnymi skrajnymi poglądami trynitarnymi. Jako antidotum na zarazę tych poglądów proponuje natychmiast swoją naukę o wcieleniu, pisząc:

„Kościelne wyznanie i wiara zbawiająca cały kosmos dotyczy wcielenia Słowa, który sam siebie dał ludzkiemu ciału (sarx), wziętemu z Maryi. Pozostał jednak sobą i w bóstwie nie uległ żadnej zmianie ani przeinaczeniu. Zlączył się z ciałem na podobieństwo ludzi, tak że powstała jedność ciała z bóstwem, gdyż bóstwo przyjęło na siebie cierpiętliwość ciała w wypełnieniu misterium"”.

Samo takie postawienie sprawy zdaje się sugerować, że zdaniem Apolinarego odpowiedź na problemy trynitarne tkwi w rozumieniu wcielenia. Jest to bardzo istotne spostrzeżenie, gdyż w „normalnym” wykładzie teologii zwykło się rozpoczynać od Trójcy Świętej, a potem dopiero przechodzi się do wcielenia. Czyniąc tak zapominamy, że Trójca Święta objawiła się nam we wcieleniu i całe nasze poznanie Trójcy musi przechodzić przez refleksję nad tą właśnie tajemnicą. Okazuje się zaś, że poglądy trynitarne są zawsze wnioskami z kontemplacji Jezusa Chrystusa, czyli Słowa Bożego wcielonego. Apolinary zdaje się więc mieć rację: rozważanie Trójcy Świętej jest niemożliwe bez założeń chrystologicznych i dlatego właśnie przedstawia błędne - jego zdaniem - poglądy trynitarne jako moźliwe do naprawienia poprzez poprawioną chrystologię.

Cytowana powyżej wypowiedź Apolinarego wskazuje, że konsekwentnie trzyma się on koncepcji zawartej w Prologu Ewangelii św. Jana: ciałem stało się Słowo, które było u Boga i było Bogiem. Trzyma się tego wiernie i co do słowa: jest napisane, że Słowo było Bogiem, a nie tylko boskie, a stało się ciałem, a nie człowiekiem. Zaraz jednak przestrzega, że nie należy na tej podstawie ani przypisywać bóstwu słabości ciała, to jest przede wszystkim cierpienia, ani też oddzielać od Słowa jako podmiotu, przypadłości ciała, jakby było oddziel-

${ }^{6}$ Por. Fides secundum partem 1, PG 10,1105; korzystam z praktycznego wydania tekstów Apolinarego w: Su Cristo. Il grande dibattito nel IV secolo, a cura di E. Bellini, Milano 1978, 26. W wydaniu tym cytowane są (ss. 26-120) jego teksty według wydania H. Lietzmanna, Apollinaris von Laodicea und seine Schule, Tübingen 1904, 168-270.

${ }^{7}$ Fides secundum partem 2, ed. Bellini s. 26-28 lub PG 10,1105 BC. 
nym podmiotem ${ }^{8}$. Syna Bożego należy kontemplować takim, jakim się ukazał w Jezusie: zdanie ewangeliczne, że nikt nie może znać Ojca, jak tylko przez Chrystusa jest tego podstawą ${ }^{9}$. Zacieśnia więc krąg i wymienia tych, którzy na temat samego już Syna Bożego mają błędne opinie:

1. Ci, którzy uważają, że jest Synem, gdyż został napełniony bóstwem;

2. Ci, którzy uważają Go za zwykłego człowieka i nie uznają w Nim Syna;

3. Ci którzy uważają Go za człowieka, przemijalnego, chociaż nawet stworzenia mają przetrwać ${ }^{10}$.

Także tych możemy z grubsza zidentyfikować: pierwsi to arianie, drudzy to zwolennicy Pawła z Samosaty, trzeci zaś to Marceli z Ancyry i spółka.

Pole działania się zawęża: prawdziwa wiara, to wiara w Syna Bożego, który od wcielenia żyje w ciele, ale równocześnie pozostaje wszechobecny, gdyż jest Bogiem ${ }^{11}$. Jego bycie synem człowieczym nie narusza w niczym bycia Synem Bożym $^{12}$. Pozostaje boskim Nous, o boskiej energii, a poruszenia ciała czy duszy są mu podległe. To On kieruje ciałem i jego poruszeniami w sposób niezawodny ${ }^{13}$. Gdyby ciało, które przyjął, stanowiło odrębny podmiot, przedmioty adoracji byłyby cztery: Ojciec, Syn Boży, Chrystus - Człowiek i Duch Święty. Tak zaś być nie może i dlatego Syn Boży i Jego człowieczeństwo muszą stanowić jedną Osobę, a wręcz jedną naturę ${ }^{14}$. Widać w tym aspekt polemiczny: nie wchodzi w rachubę połączenie się Słowa z już ukształtowanym człowiekiem, gdyż byłyby wtedy dwie osoby, ale ukształtowanie człowieka przez wcielenie Słowa ${ }^{15}$. Dystansuje się w ten sposób od Pawła z Samosaty, zdaniem którego Synem Bożym jest Jezus - Człowiek, do którego (na którego) zstąpiło Boże Słowo, wcześniej nie istniejące jako odrębna hipostaza.

Dalszych precyzacji poszukajmy w jego traktacie O jedności ciała z bóstwem w Chrystusie. Aby Słowo mogło utworzyć z przyjętym ciałem jedną naturę, ciało to nie może oznaczać pełni człowieczeństwa, które mogłoby aspirować do własnej podmiotowości ${ }^{16}$. Niestworzone i stworzone stanowią w Chrystusie jedną naturę, gdyż tak jak dusza rozumna w każdym człowieku, tak w Nim Słowo jest energią ożywiającą to ciało ${ }^{17}$. Dalej w swej niestworzoności pozostaje On współistotny Ojcu, zaś w swej stworzoności - współistotny z ludźmi. Jest jednak jeden $^{18}$. Taka, a nie inna kondycja Chrystusa wyjaśnia się poprzez

\footnotetext{
${ }^{8}$ Por. tamże, 3 .

${ }^{9}$ Por. tamże, 4 .

${ }^{10}$ Por. tamże, 6, ed. Bellini s. 28-30, PG 10,1108B.

11 Por. tamze, 11.

12 Por. tamze, 27.

13 Por. tamze, 30.

14 Por. tamże, 31.

15 Por. tamże, 34 i 36.

${ }^{16}$ Por. De unione corporis et divinitatis in Christo 1, ed. Bellini s. 48.

${ }^{17}$ Por. tamże, 5, ed. Bellini s. 50.

${ }^{18}$ Por. tamże, 8.
} 
Jego dziewicze narodziny. Zgodnie ze starożytnymi poglądami fizjologicznymi, całość mającej się urodzić osoby ludzkiej jest zawarta w nasieniu mężczyzny. Matka jest środowiskiem, w którym mały człowieczek wzrasta i formuje swoje ciało. W przypadku Jezusa nie ma żadnego ludzkiego nasienia, ale ,zostaje udzielona Dziewicy moc duchowa i boska" ${ }^{\text {, }}$, czyli Słowo Boże, czyli boski Nous, który formuje swoje ciało w analogii do działania nasienia mężczyzny. Świadczy też o tym choćby sam tytuł jednego z jego pism, krytykowanego przez Grzegorza z Nyssy: Rozważanie o boskim wcieleniu na podobieństwo człowie$k a^{20}$.

Traktowanie łona matki jako gleby, w której wyrasta wsiane ziarno, nie było naonczas niczym oryginalnym ani szokującym; odkrycie genów i komórki jajowej to na razie śpiewka dalekiej przyszłości. By zastosować takie porównanie do Chrystusa, trzeba było jednak dokonać pewnych uszczegółowień natury antropologicznej. Epifaniusz z Salaminy streścił poglądy Apolinarego w tej materii w takich oto słowach:

„Człowiek jest hipostazą dzięki swojemu umysłowi (nous), który jest zasadą życia. Jego dusza ożywiona (psyche) i jego ciało mają swoją hipostazę „,w” i „poprzez” umysł. Jeżeli więc Słowo, jako boski Nous i boski Duch, przyjęło umysł człowieczy, są w Chrystusie dwie hipostazy, co jest niemożliwe. Jeśli zaś, przeciwnie, przyjęło tylko ciało i duszę ożywioną, mają one swoją hipostazę w Nim i Chrystus jest tylko jedną hipostazą"21.

Wygląda z tego, że zdaniem Apolinarego człowiek otrzymuje nous od ojca, zaś od matki ciało i duszę ożywioną. Zasadą osobowości jest nous, bez którego nie utworzyłoby się ani ciało, ani dusza. Ze zwykłym człowiekiem sprawa jest prosta: nous jest ludzki, ciało i dusza też, nie ma więc wątpliwości, że owocem takiego połączenia jest osoba i natura ludzka. W przypadku Jezusa jednak nie ma ludzkiego nous, nie ma więc pełnej natury ludzkiej. Wskutek wcielenia Słowa powstaje zatem coś bardzo szczególnego i jednorazowego ${ }^{22}$, jakaś natura, którą określa jako bosko-ludzką mieszaninę, jako „,człowieka niebiańskiego"23. By pobudzić ludzką wyobraźnię, Apolinary pisze między innymi:

„Byty pośrednie powstają, kiedy różne właściwości wchodzą w złożenie konstytuując jedną rzecz, jak na przykład cechy osła i konia [łączą się] w mule i cechy białego i czarnego w szarym, a na niebie właściwości zimy i lata tworzą wiosnę.

${ }^{19}$ Por. tamże, 13.

${ }^{20}$ Por. Demonstratio de divina incarnatione ad similitudinem hominis (CPG 3652), ed. Lietzmann s. 208-232, ed. Bellini s. 58-64.

21 Ancoratus 77, PG 43, 161.

22 Por. Ad Diodorum, frag. 140, ed. Bellini s. 80.

23 Por. frag. 89-90, w: Gregorius Nyssenus, Antirrheticus adversus Apollinarium 50, PG 45, 1244-1245, ed. Bellini s. 454-455; zob. E. Cattaneo, Il Cristo „Uomo celeste” secondo Apollinare di Laodicea, RivStLitRel 19 (1983) 415-419. 
Nigdy jednak byt pośredni nie zawiera wszystkich skrajności, ale są one w nim częściowo. Tak więc w Chrystusie jest byt pośredni z Boga i człowieka. Nie jest On cały człowiekiem, ani Bogiem, ale zmieszaniem (mixis) Boga i czlowieka ${ }^{24}$.

Skutkiem wcielenia miałaby być zatem natura bosko-ludzka, jedna osoba, jedna hipostaza, a także jedna natura i jedna energeia, oczywiście boska ${ }^{25}$. Sam Apolinary zdaje sobie sprawę, że takie opisywanie Słowa wcielonego może prowadzić na błędne drogi. Można by na przykład sądzić, że Słowo przekształciło się w człowieka. Na taki zarzut odpowiada tym samym przykładem, jaki Orygenes odniósł do związku Logosu z tym bytem rozumnym, który miał się na ziemi stać Jego duszą ${ }^{26}$ : mówi mianowicie o żelazie zanurzonym w ogniu. Żelazo przejmuje cechy ognia, to znaczy jest gorące jak ogień, ale przez to nie przestaje być żelazem. Podobnie, zdaniem Apolinarego, ciało złączone ze Słowem przyjmuje Jego cechy i działa jak Ono, ale nie przestaje być ciałem ${ }^{27}$. Innym przykładem jest człowiek, który z powodu połączenia pierwiastka rozumnego (nous) z nierozumnym (ciało i dusza ożywiona), nie staje się nierozumny: tak i Słowo niestworzone łącząc się z stworzonością nie staje się stworzeniem $^{28}$. Innymi słowy mówiąc, jak dusza nie przemienia się $\mathrm{w}$ ciało, tak i Logos nie przemienia się w ciało ${ }^{29}$. Gdyby do takiej przemiany doszło, Logos musiałby stać się śmiertelny, ziemski, podległy grzechowi itd. Tak zaś nie jest, bowiem Chrystus zwycięża śmierć, określa się Go jako pochodzącego z nieba (1 Kor 15, 47) i wyzwalającego od grzechu (Mt 1, 21). Nie może więc być człowiekiem $^{30}$. Raczej należałoby Go określić jako „człowieka niebiańskiego”, ponieważ oprócz ciała i duszy posiada Intelekt (nous), który jest Bogiem ${ }^{31}$.

Z punktu widzenia ontologii skutkiem wcielenia jest więc pojawienie się na ziemi Słowa Bożego w ludzkim ciele, jako „człowieka niebiańskiego”, w jednej naturze i substancji Boga i człowieka. Z przykładów o mieszaninie, jakie widzieliśmy, można by wywnioskować, że zdaniem Apolinarego Chrystus jest bytem pośrednim między bóstwem i człowieczeństwem. Tak jednak wbrew pozorom nie jest. Bóstwo Syna Bożego pozostaje takim jakie było i nie nastąpiła w nim żadna zmiana, natomiast człowieczeństwo pozostaje niekompletne. W oficjalnym piśmie zwanym Tomus synodalis pisze o tym jeszcze raz, wskazując również na zbawcze tego skutki dla ludzi:

\footnotetext{
${ }^{24}$ Syllogismi frag. 113, ed. Bellini s. 74, ed. Lietzmann s. 233.

25 Por. Oratio de fide et incarnatione 3 i 6, ed. Bellini s. 58-60.

${ }^{26}$ Por. De principiis II 6,6.

27 Por. Ad Diodorum frag. 128, ed. Bellini s. 78 .

${ }^{28}$ Por. tamże, frag. 132, ed. Bellini s. 78.

${ }^{29}$ Por. tamze, frag. 134, ed. Bellini s. 80.

${ }^{30}$ Por. tamże, frag. 146, ed. Bellini s. 82.

${ }^{31}$ Por. frag. 25, w: Gregorius Nyssenus, Antirrheticus adversus Apollinarium 10, PG 45, 1144 , ed. Bellini s. 354; zob. też frag. 163 (Ad Terentium), ed. Bellini s. 98.
} 
„Żywe Słowo Boże przyjęło z Maryi ciało współistotne naszemu, jednocząc je z bóstwem od samego poczęcia w Dziewicy i tak stało się człowiekiem. Według apostoła człowiek jest duszą i ciałem. Tak więc Słowo stało się ciałem łącząc się z ciałem jak ludzki duch. Człowiek taki, jak my nazywa się ciałem. Pan jest jednak człowiekiem większym od nas, i dlatego nazywa się «niebiańskim», gdyż Jego duch jest niebiański i odczucia cielesne nie stanowią dla niego przeszkody. Dlatego też w Chrystusie odpuszczony został grzech i pognębiona śmierć pochodząca z grzechu. My zaś, uczestnicząc w tej doskonałości przez wiarę, zostajemy zbawieni i upodobniamy się do «niebiańskiego», choć mamy ojca ziemskiego"32.

Rzuca się w oczy, że największym niebezpieczeństwem w oczach Apolinarego było przyznanie Chrystusowi prawdziwego, integralnego człowieczeństwa. Bóstwo Logosu jest dla niego oczywiste na podstawie Ewangelii św. Jana. W przeciwieństwie do arian, ale także do zdecydowanej większości swoich współczesnych, wierzy, że Syn jest nie tylko współistotny Ojcu, ale wręcz wyznaje jedną ousia i jedną hypostasis Trójcy ${ }^{33}$. Jego zdaniem to o tym właśnie mówiono na soborze w Nicei:

„Jeśli ktoś myli się i myśli oraz uczy inaczej niż nauczyli nas prorocy, apostołowie i nasi święci Ojcowie zebrani z całego świata w Nicei, wystawia się na wielkie niebezpieczeństwo, ponieważ On rzekł: «Błogosławiony, kto nie gorszy się ze mnie» (Mt 11, 6). A taki gorszy się z powodu ciała i z powodu części, która cierpiała, zmienia naszego Zbawiciele i traktuje Go jako człowieka, a nie Boga. Bowiem kto nazywa człowiekiem tego, kto urodził się z Maryi i człowiekiem tego, który zostal ukrzyżowany, czyni z Niego człowieka, a nie Boga"34.

Znane nam relacje o obradach Soboru Nicejskiego, tak jak są one rozumiane w prawie wszystkich dotychczasowych opracowaniach, nic takiego nie zawierają. Patrzymy bowiem na ten sobór przez okulary św. Atanazego, i to te, które założył dopiero 25 lat po zakończeniu soboru, kiedy to zaczął go bronić w sensie antyariańskim, po licznych nieudanych próbach skonstruowania nowego wyznania wiary, na przykład w Sardyce w 343 roku. Niewiele też zmieniają tę perspektywę relacje Euzebiusza z Cezarei, które skupiają się na zewnętrznościach i cesarskim splendorze. Jakimś odblaskiem dyskusji na wskazany przez Apolinarego temat może być jedynie 19 kanon soboru, w którym uznaje się za nieważny chrzest zwolenników Pawła z Samosaty. Nie jest wykluczone, że temat ten zaprzątał uwagę Ojców dość intensywnie, gdyż nawet w anatematyzmie dołączonym do wyznania wiary widać akcenty antypauliniańskie - obok antyariańskich.

${ }^{32}$ Frag. 164 (Tomus synodalis), ed. Lietzmann s. 262, ed. Bellini s. 106.

${ }^{33}$ Por. Fides secundum partem 10 i 25, ed. Bellini s. 30 i 38; zob. Athanasius, Epistula ad Antiochenos i całego Synodu Wyznańców w 362 roku.

${ }^{34}$ Oratio de fide et incarnatione 9, ed. Bellini s. 64. 
Alois Grillmeier przypuszcza, że chrystologia Apolinarego jest uprzednia względem chrystologii ariańskiej i pisze, że „,arianizm jest jedynie rozwojem podstawowych zasad apolinaryzmu" 35 . By to uprawomocnić, szuka apolinaryzmu przed Apolinarym, gdyż ten zaczął tworzyć dopiero w latach pięćdziesiątych IV wieku. Wzięło się to prawdopodobnie stąd, że za Atanazym uznaje się powszechnie za arianizm przede wszystkim pogląd o stworzoności Logosu, natomiast Ariuszowe poglądy chrystologiczne za konsekwencję powyższego. Uważam, że było odwrotnie ${ }^{36}$, zgodnie ze słowami Apolinarego, który właśnie w chrystologii widzi remedium na błędy trynitarne. Tak więc arianizm zaczął się raczej od kwestii chrystologicznej: jeśli Jezus Chrystus wysłużył nam zbawienie, Jego posłuszeństwo Ojcu było zasługujące. Można zaś mówić o zasłudze tylko wtedy, gdy działanie jest związane z wolnym wyborem, a nie zdeterminowane naturą. Zdaniem Pawła z Samosaty, grosso modo, Jezus był człowiekiem, który za swe zasługi został „adoptowany” na Syna Bożego. Ariusz się temu sprzeciwił uważając zapewne, że działanie czysto ludzkie nie wystarczy do zbawienia świata. Za wszelką cenę jednak starał się utrzymać zasługę Chrystusa, czyli podkreślić Jego posłuszeństwo. To zaś wyobrażał sobie jako związane z możliwością nieposłuszeństwa. Aby to pogodzić, musiał odmówić wcielonemu Logosowi boskiej niezmienności, czyli boskiej natury.

Altaner pisze, że Apolinary ,pod wpływem arianizmu przeczył ludzkiej naturze Chrystusa"37. Rzeczywiście istnieje taka zbieżność, sądzę jednak, że nie ma tu naśladownictwa, ale po prostu to samo teologiczne zmartwienie, spowodowane teologią Pawła z Samosaty. Apolinary nie zgadzał się z nim podobnie jak Ariusz, nie chciał jednak przyjąć ariańskiego rozwiązania, które w rezultacie doprowadzało do negacji bóstwa Logosu. Cóż więc mu pozostało? Także on uważał, że ludzkie działanie Chrystusa nie miałoby mocy zbawczej: do tego potrzeba działania Bożego. Pozostawał jednak wyakcentowany przez Ariusza problem woli Chrystusa. Apolinary sądził, że nie może tutaj być konfliktu: gdyby w Chrystusie natury - boska i ludzka - były kompletne, współistniałyby w Nim dwie wole, a to, jego zdaniem, koniecznie doprowadziłoby do rywalizacji pomiędzy nimi:

„Jeśli każdy nous jest autonomiczny (autokrator) kierując się wolą zgodnie ze swoją naturą, niemożliwą jest rzeczą, by w jednym podmiocie istniały dwie wole przeciwstawne sobie, gdyż wtedy każda $z$ nich działałaby samodzielnie zgodnie z własnym wyborem" 38 .

${ }^{35}$ Por. Grillmeier, Gesù il Cristo s. 609.

36 Por. mój artykuł o powodach zwołania Soboru Nicejskiego: Le ragioni della convocazione del Concilio Niceno da parte di Costantino il Grande, „Gregorianum” 82(2001) 5-35.

37 Por. B. Altaner - A. Stuiber, Patrologia, thum. W. Pachciarek, Warszawa 1990, 424.

${ }^{38}$ Fragmentum 150 (Ad Julianum), ed. Bellini s. 90; por. też frag. 2. 
Widać, że Apolinary jest dość pesymistycznie nastawiony do człowieka jako takiego. Wyszczególnia cechy ludzkie, by wykazać, że Chrystus nie był taki. Czyni to dość systematycznie w Streszczeniu ujętym we fragmencie 146: Każdy człowiek jest częścią świata (2), jest poddany śmierci (3), podlega grzechowi (9), istnieje w nim kontrast między ciałem a intelektem (10), musi umartwiać ciało, by osiągnąć doskonałość (11), jest „starym człowiekiem” $(23)^{39}$. Takim zaś Chrystus nie był, nie można więc mówić, że był takim człowiekiem jak my. Trzeba przyznać, że bardzo trudno przychodzi Apolinaremu utrzymywać konsekwentnie, że Chrystus nie był człowiekiem, a równocześnie nim był; konkluzja jest jednak właśnie taka: Jezus Chrystus jest Synem Bożym i Bogiem w ludzkim ciele. Tylko Bóg bowiem może zbawić, tylko Bóg może dać życie, tylko Bóg może wskrzeszać umarłych.

$\mathrm{Z}$ takiego postawienia sprawy można wnosić, że Apolinary skonstruował taką a nie inną koncepcję chrystologiczną w odpowiedzi na to samo pytanie, jakie skłoniło Ariusza do negacji bóstwa Logosu. Wspólne u obu jest zanegowanie pełni człowieczeństwa Jezusa. U Ariusza jednak, któremu zależało na podkreśleniu zasługującego posłuszeństwa Jezusa, doszło do nazwania Logosu zmiennym z natury, czyli nie - Bogiem. U Apolinarego natomiast wydaje się niepodważalne prawdziwe bóstwo Jezusa, gdyż on sam raczej uważał swój przykład mieszaniny za niezbyt szczęśliwy. Tak ważną dla Ariusza możliwość zmian w Chrystusie, Apolinary odnosi tylko do ciała i w niczym nie wpływa ona na naturalną stałość boskiej woli Logosu. Oba poglądy chrystologiczne są więc monoteletyczne. Dla Ariusza jedna wola Chrystusa jest z natury zmienna i decydujące dla zbawienia jest posłuszeństwo Chrystusa; Chrystus jest niezmienny de facto, ale nie de natura. Dla Apolinarego zaś wola ta jest niezmienna, tak więc zbawienie jako skutek wcielenia nie jest owocem posłuszeństwa Chrystusa, ale zbawczej woli Boga.

Dla teologów myślących „biało-czarno”, to znaczy aplikujących do starożytności wypracowane później pojęcia ortodoksyjności, istnieje kłopot z pogodzeniem osobliwych poglądów Apolinarego z jego przyjaźnią z Atanazym, jak by nie było, uznanym za filar prawowierności. Wielu powołuje się tutaj na atanazjański List do Antiocheńczyków, będący wypowiedzią Synodu Wyznawców z 362 roku na ten temat, który miał m.in. potępiać poglądy apolinarystycz$n \mathrm{e}^{40}$. Nie jest to jednak wcale tekst jednoznaczny. Na temat natury Chrystusa czytamy w nim:

„Wszyscy wyznali, że Zbawiciel nie posiadał ciała bez duszy, pozbawionego zmysłów i rozumu, ponieważ nie byłoby to możliwe, żeby Pan stawszy się człowiekiem z. $15,1027$.

${ }^{39}$ Por. fragmentum 146 (Recapitulatio), ed. Bellini s. 82-86, ed. Lietzmann s. 242-246.

${ }^{40}$ Por. wstęp A. Gołdy do swojego tłumaczenia Listu do Antiocheńczyków, VoxP 8(1988) 
dla nas, posiadał ciało pozbawione rozumu (ảvóptov), zaś zbawienie zrealizowane w Slowie dotyczyło nie tylko ciała, lecz i duszy $(\psi v \chi \tilde{\eta} \varsigma)^{41}$.

Wbrew pozorom takie brzmienie tekstu w niczym nie mogło przeszkadzać Apolinaremu, gdyż jak widzieliśmy, przyjmował on w Chrystusie ludzkie ciało i psyche, nie widział tylko miejsca dla ludzkiego nous, który został zastąpiony przez Nous boski, czyli Słowo. Nie ma też raczej powodu, by wietrzyć tu interpolację, jak w przypisach do tego miejsca w polskim przekładzie ${ }^{42}$, gdyż zdanie to jest zupełnie zgodne $z$ wieloma twierdzeniami Atanazego ${ }^{43}$. Był on znacznie bardziej przejęty konsekwencjami trynitarnymi chrystologii Ariusza, niż jego chrystologią, i choć sam pisał wiele o wcieleniu, przede wszystkim kładł akcent na bóstwo Logosu, a nie na opisywanie pełni człowieczeństwa Jezusa Chrystusa $^{44}$. Nie ma w tym nic dziwnego, gdyż mam wrażenie, że wszelkie zatrzymywanie się na człowieczeństwie Chrystusa wiązało się wówczas z ryzykiem popadnięcia pod paragrafy wymierzone w Pawła z Samosaty, a od niego Synod Wyznawców też wyraźnie się odgradzał ${ }^{45}$.

Kończąc tych kilka spostrzeżeń, można by napisać co następuje: Apolinary podjął poszukiwania nowej formuły chrystologicznej zdając sobie sprawę z niewydolności dotychczasowych rozwiązań, pomiędzy Pawłem z Samosaty a Ariuszem. Pierwszy akcentował człowieczeństwo Chrystusa i doszedł do negacji realnego istnienia Syna Bożego przed wcieleniem. Drugi podkreślał posłuszeństwo i w efekcie zanegował bóstwo Logosu, przyznając mu jednakowoż istnienie od początku czasów. Apolinary zatem, dla uratowania zbawiającej woli Bożej sprawiającej zbawienie, umniejszył człowieczeństwo Jezusa, pozbawiając Go ludzkiej woli, która mogłaby stać w opozycji do woli Logosu, współistotnego z Ojcem. Bezkompromisowe opowiedzenie się za bóstwem Logosu zaskarbiło mu sympatię Atanazego, który również bał się mówienia o kompletności ludzkiej natury Chrystusa, widząc w tym - być może - niebezpieczeństwo popadnięcia w błędy Pawła z Samosaty.

41 Tomus ad Antiochenos 7, PG 26, tłum. A. Gołda, VoxP 8(1988) z. 15, 1035.

${ }^{42}$ Por. tamże, s. 1036 n. 11.

43 Por. Grillmeier, Gesù il Cristo, dz. cyt. s.600-601.

${ }^{44}$ Por. Ch. Kannengiesser, Le Verbe de Dieu selon Athanase d'Alexandrie, Paris 1990, 126; Grillmeier, Gesù il Cristo, I/1, cz. 2, rozdz. 4, 583 nn.

45 Por. Tomus ad Antiochenos 3. 


\section{L'INCARNAZIONE DEL VERBO DI DIO NELLA TEOLOGIA DI APOLLINARE DI LAODICEA SULLO SFONDO DELLA CONTROVERSIA ARIANA}

(Riassunto)

Apollinare si è opposto alla teologia ariana richiamando i principi di cristologia, cercando una nuova soluzione del problema creatosi con la teologia nota sotto il nome di Paolo di Samossata. Questi, infatti, accentuando l'umanità di Cristo è giunto alla negazione della sua reale esistenza in quanto Figlio di Dio prima dell'incarnazione. Ario invece accentuava l'obbedienza salvifica di Cristo e in effetti negò la sua divinità, necessariamente legata all'immutabilità, tuttavia riconoscendo la sua esistenza dal prima dei tempi. Apollinare, per salvaguardare la volontà salvifica di Dio ha ridotto l'integrità della natura umana di Cristo privandolo della volontà umana, perché questa potrebbe - a suo avviso - contrastare con la volontà del Logos, consustanziale al Padre. La fede dichiarata nella divinità del Logos gli ha guadagnato la simpatia di Atanasio, il quale - pure lui - si sentiva imbarazzato di fronte alla necessità di parlare della piena natura umana di Cristo. Il fatto che Apollinare sposta il peso della controversia ariana sul piano cristologico, contrariamente a Atanasio, il quale vi è visto soprattutto un errore trinitario, sembra suggerire che di fatto anche per Ario il problema cominiciasse con dei temi cristologici, non tanto trinitari. 